\title{
Pemanfaatan Teknologi Informasi Berbasis Android Sebagai Media dalam Pembelajaran Hindu
}

\author{
Ni Putu Eka Merliana \\ IAHN Tampung Penyang Palangka Raya \\ Email : putuekamerliana@gmail.com
}

\begin{tabular}{|c|c|}
\hline \multicolumn{2}{|c|}{$\begin{array}{l}\text { Riwayat Jurnal } \\
\text { Artikel diterima: } 8 \text { Maret } 2018 \\
\text { Artikel direvisi: } 15 \text { Mei } 2018 \\
\text { Artikel disetujui: } 1 \text { Juni } 2018\end{array}$} \\
\hline \multicolumn{2}{|r|}{$\begin{array}{l}\text { Abstrak } \\
\text { Saat ini perkembangan teknologi informasi sangat pesat dimana } \\
\text { hal ini dapat mempengaruhi kehidupan masyarakat secara umum } \\
\text { baik itu dibidang sosial, ekonomi, politik maupun pendidikan. } \\
\text { Pendidikan menjadi salah satu bidang yang menjadi sorotan } \\
\text { pemerintah untuk menghasilkan generasi muda yang cerdas dan } \\
\text { siap bersaing, dimana sangat dibutuhkan adanya suatu kemajuan } \\
\text { proses pembelajaran yang dapat membantu memajukan sistem } \\
\text { pendidikan. Salah satunya adalah dengan menerapkan } \\
\text { penggunaan media pembelajaran berbasis teknologi informasi. } \\
\text { Agama Hindu merupakan salah satu agama yang ada di Indonesia } \\
\text { memerlukan cara untuk menerapkan sistem pembelajaran dengan } \\
\text { teknologi dalam penyampaian ajaran agamanya. Salah satu media } \\
\text { teknologi pembelajaran yang paling banyak dipergunakan } \\
\text { dikalangan masyarakat secara umum adalah teknologi android, } \\
\text { dimana media ini diharapkan dapat memberikan simulasi dalam } \\
\text { pembelajaran Hindu agar lebih memahami dan mendalami tentang } \\
\text { ajaran-ajaran yang telah diberikan kepada siswa. Oleh karena itu } \\
\text { penulis ingin mengangkat tentang seberapa pentingnya manfaat } \\
\text { teknologi berbasis android dalam pembelajaran Hindu }\end{array}$} \\
\hline Kowuard. & \\
\hline
\end{tabular}


expected to provide a simulation in Hindu learning in order to better understand and explore the teachings that have been given to students. Therefore the authors want to raise about how important the benefits of android-based technology in Hindu learning

\section{Pendahuluan}

Perkembangan teknologi sangat berpengaruh terhadap kehidupan manusia baik itu dibidang pendidikan, sosial, agama, politik maupun ekonomi yang sangat menentukan kemajuan dari suatu negara. Ada beberapa jenis fungsi dari teknologi informasi dilihat dari segi penggunaannya antara lain sebagai media komunikasi, media penyebaran maupun media pembelajaran. Berdasarkan data UNESCO (2000) tentang peringkat Indeks Pengembangan Manusia (Human Development Index), dimana komposisi peringkat pencapaian pendidikan di Indonesia mengalami penurunan. Diantara 174 negara di dunia, Indonesia menempati urutan ke-102 (1996), ke-99 (1997), ke 105 (1998) dan ke-109 (1999). Menurut survei Political and Economic Risk Consultant (PERC) kualitas pendidikan Indonesia berada pada urutan ke 12 dari 12 negara di Asia. Sedangkan menurut The World Economic Forum Swedia (2000), daya saing yang dimiliki oleh Indonesia dinilai rendah dimana Indonesia menduduki urutan ke 37 dari 57 negara yang telah disurvei oleh dunia (Amanda, 2018). Berdasarkan fenomena ini menjadikan perhatian pemerintah terhadap penanganan masasalah di bidang pendidikan salah satunya adalah pembenahan sistem pembelajaran yang ada selama ini, karena dengan adanya sistem pembelajaran yang baik dan inovatif akan menghasilkan generasi muda yang berkualitas dan siap bersaing. Berbagai macam cara digunakan untuk memperbaiki sistem pembelajaran saat ini salah satunya adalah dengan menggunakan suatu media pembelajaran berbasis teknologi informasi, dimana dapat proses belajar mengajar akan menjadi lebih menyenangkan dan bervariasi.

Pondasi dari tingkah laku dan perilaku generasi muda dalam kehidupan bermasyarakat adalah ajaran agama, dimana semua agama mengajarkan bagaimana seseorang untuk percaya akan adanya Tuhan sehingga dalam kehidupannya akan selalu melakukan perbuatan yang baik. Ajaran Agama Hindu yang merupakan salah satu agama tertua yang ada di Indonesia, memberikan ajaran yang berlandaskan pada kitab suci Weda. Pembelajaran Agama Hindu diajarkan kepada generasi muda melalui pendidikan sekolah agar siswa(i) dapat memahami lebih mendalami ajaran agama Hindu melalui pendidikan formal dengan memberikan contoh postif dalam berperilaku sesuai dengan ajarannya. Dalam pembelajaran Hindu perlu adanya 
suatu perubahan sistem dalam proses belajar mengajar agar tidak monoton sehingga siswa(i) dapat lebih memahami pengetahuan yang diajarkan tersebut. Salah satu inovasi yang digunakan adalah dengan media teknologi informasi berbasis android.

Teknologi android menjadi salah satu teknologi komunikasi yang sangat pesat perkembangannya dimana semua penggunanya baik tua maupun muda sudah menggunakan teknologi tersebut. Android menjadi teknologi yang paling digemari, hal ini disebabkan karena mudah digunakan dan dapat mengakses apa saja dimana saja dan kapan saja. Dari hasil survei teknologi android lebih banyak dipergunakan oleh anak muda saat ini dimana teknologi tersebut digunakan sebagai gaya hidup di jaman era globalisasi sekarang ini. Menurut Rahma (2015) sebanyak 39\% kebanyakan smartphone atau android digunakan oleh anak yang berusia antara 16 sampai 21 tahun karena kebanyak generasi muda dapat dengan mudah mengikuti perkembangan teknologi yang ada. Selain itu Julia Purbasari (1988) telah melakukan penelitian dengan membagikan angket yang berisikan beberapa pertanyaan kepada para siswa kelas $\mathrm{X}$ SMAN 10 Malang, dari hasil tersebut didapat bahwa seluruh siswa rata-rata memiliki smartphone/android serta ada beberapa mahasiswa dengan jumlah 57 siswa yang memiliki komputer atau laptop. Dari fenomena tersebut didapat bahwa generasi muda sekarang sebagian besar memiliki android dibandingkan komputer atau laptop, sehingga untuk memperbaiki sistem pembelajaran yang ada terutama untuk pembelajaran Hindu dapat digunakan media teknologi android sebagai salah satu media interaktif untuk pembelajaran Hindu agar sistem pembelajaran yang monoton dan membosankan bisa menjadi lebih menyenangkan serta menjadi lebih interaktif. Maka dari itu penulis ingin mengangkat topik seberapa pentingnya penggunaan teknologi android dalam pembelajaran Hindu dikalangan generasi muda Hindu baik itu dari segi pemanfaatan dari media tersebut dengan memperhatikan aspek penyebaran ajaran agama Hindu.

\section{Pembahasan}

\section{Perkembangan Teknologi Informasi dan Teknologi Komunikasi}

Pada jaman sekarang banyak sekali revolusi atau perubahan baik itu dari revolusi industri, sampai revolusi kehidupan masyarakat secara umum yang akan berdampak kepada semua sektor yang berhubungan yaitu sektor ekonomi, pendidikan, kebudayaan maupun sosial. Dengan adanya revolusi tersebut akan menghasilkan inovasi terhadap teknologi informasi dan teknologi komunikasi. Sepintas Teknologi Informasi dan Teknologi Komunikasi memiliki 
makna yang sama padahal dari kedua piranti atau media tersebut memiliki kegunaan dan fungsi yang sedikit berbeda. Menurut Harun (2015), suatu perangkat dikatakan teknologi informasi adalah jika perangkat tersebut dapat mengolah data sehingga akan menghasilkan suatu informasi yang bermanfaat, berkualitas serta relevan sesuai dengan kebutuhan pengguna, sedangkan suatu perangkat dikatakan teknologi komunikasi adalah perangkat yang dapat memproses dan mengkomunikasikan semua data yang masuk ke perangkat tersebut sehingga perangkat itu dapat berkomunikasi dengan perangkat lainnya. Dengan perkembangan teknologi informasi dan komunikasi yang semakin pesat menjadikan para pakar untuk membuat sebuah inovasi yang disesuaikan dengan beberapa bidang baik itu dibidang pendidikan, ekonomi maupun sosial dan budaya. Adapun beberapa teknologi yang sedang berkembang saat ini antara lain sebagai berikut :

\section{Teknologi Augmented Reality (AR)}

Saat ini teknologi berkembang sangat pesat, dimana salah satu teknologi yang banyak digunakan adalah teknologi augmanted reality, karena teknologi ini menampilkan visualisasi suatu benda seolah-olah berada dilingkungan nyata. Sudah banyak yang mempergunakan teknologi tersebut misalnya dipergunakan dalam bidang kesehatan, pariwisata sampai ke bidang pendidikan. Menurut Wardani (2015, hal. 1-2) teknologi Augmented Realtity (AR) merupakan teknologi yang menggabungkan antara benda maya kedalam sebuah lingkungan nyata sehingga akan menampilkan benda seolah-olah benda itu menjadi nyata. Contoh teknologi yang menggunakan teknologi Augmented Reality (AR) pada permainan dengan menggunakan smartphone adalah permainan Pokemon Go, dimana pemain akan melatih, mempertarungkan maupun menangkap karakter pokemon yang berada di lingkungan nyata. Contoh lain dengan menggunakan teknologi tersebut adalah penelitian yang dilakukan (Wardani, 2015), dimana penelitian ini memanfaatkan teknologi Augmented Reality sebagai teknologi dalam pengenalan aksara jawa. Menurutnya pembelajaran aksara jawa sangatlah sulit, karena harus memperkenalkan beberapa pelafalan sehingga menjadi sebuah kata maupun kalimat. Selain itu sudah pernah dilakukan pembuatan visualisasi dengan menggunakan alat peraga pembelajaran aksara jawa misalnya menggunakan kertas berwarna, namun alat tersebut gampang rusak dan mudah hilang. Sehingga dibuatlah sebuah perangkat yang dapat menjelaskan suatu objek Aksara Jawa dengan menggunakan Teknologi Augmanted Reality sehingga objek tersebut dapat ditampilkan secara menyeluruh dalam bentuk tiga dimensi dan pembelajaran siswa mengenai pengenalan Aksara Jawa akan menjadi lebih menyenangkan. 
Untuk melihat secara garis besar proses Teknologi Augmented Reality dapat dilihat pada gambar 1 .

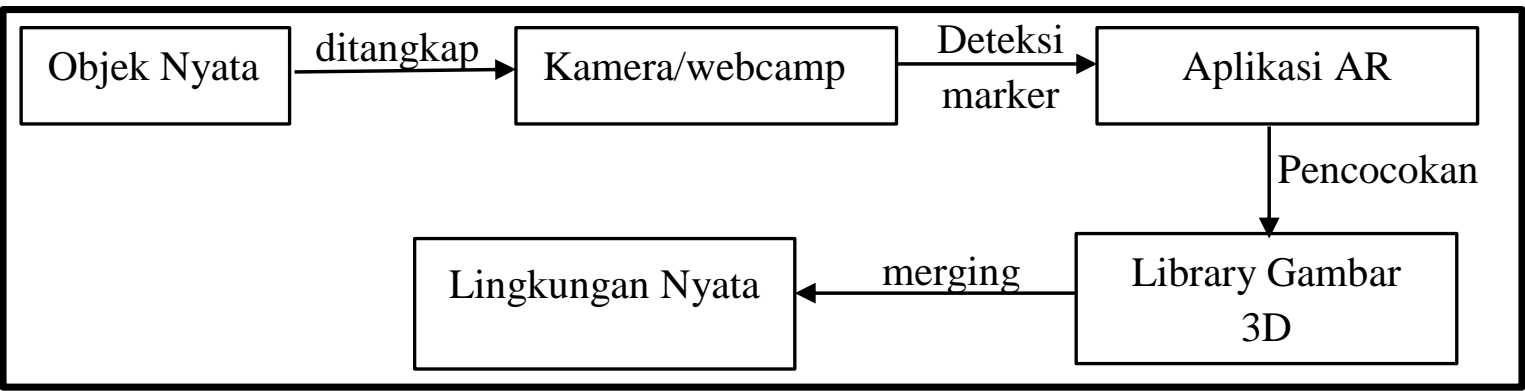

Gambar 1

User atau pengguna akan mengarah objek yang akan ditangkap oleh kamera atau webcamp sebagai jembatan penghubung ke dunia nyata, kemudian gambar atau objek tersebut akan dikenali oleh suatu software atau aplikasi Augmented Reality yang dapat mendeteksi gambar tersebut. Setelah terdeteksi maka akan dicocokkan dengan gambar objek 3D yang telah tersimpan di aplikasi, jika sama maka gambar 3D akan digabungkan dan dimunculkan sehingga user dapat berinteraksi dengan gambar tersebut dan user dapat menggerakkan gambar 3D ke lingkungan nyata yang ada di sekitar

\section{Teknologi Kecerdasan Buatan}

Teknologi Kecerdasan Buatan merupakan teknologi yang dibuat dengan menggunakan berbagai macam algoritma atau perhitungan untuk mengadopsi berbagai jenis keahlian ilmu yang diimplementasikan ke sebuah aplikasi atau software. Rachman, Suhartono, $\&$ Purwanto (2010) membuat suatu agen cerdas yang merupakan bagian dari teknologi kecerdasan buatan, dimana sistem agen cerdas yang dibuatnya adalah untuk memberikan pembelajaran kebudayaan dengan membuat media game ringan untuk mempopulerkan kebudayaan di Indonesia. Berdasarkan sudut pandangnya Kecerdasan Buatan memiliki beberapa sifat yaitu berdasarkan kemampuan bahwa komputer melakukan segala sesuatu yang dapat dilakukan oleh manusia sebagai mahluk yang cerdas dan berdasarkan kemampuan para pakar atau peneliti dimana kecerdasan buatan dapat menjadi sistem pakar yang keilmuannya diambil dari peneliti tersebut. Teknologi Kecerdasan Buatan sudah banyak dilakukan dibidang kesehatan untuk mendeteksi beberapa penyakit. Salah satu contoh penelitian yang dilakukan oleh (Latumakulita \& Montolalu, 2011) dalam penelitiannya merancang dan membuat suatu sistem pakar yang dapat mendeteksi penyakit ginjal. Pertama kali yang dilakukan sistem pakar untuk mendeteksi penyakit ginjal adalah dengan mengumpulkan data terlebih dahulu (Akusisi 
Pengetahuan), setelah mengumpulkan data maka dibuatlah suatu tabel keputusan yang dijadikan aturan dalam pendeteksian penyakit ginjal misalnya data yang diambil adalah ciri-ciri yang dialami oleh penderita penyakit ginjal. Semua data-data tersebut akan disimpan dalam suatu database dimana semua data tersebut akan diakses oleh software sistem pakar.

3. Teknologi multimedia

Dalam jaman yang serba modern ini, persaingan dan inovasi sangat diperlukan untuk memajukan segala pekerjaan untuk menghadapi persaingan secara global. Salah satu yang dapat dilakukan untuk berinovasi adalah dengan menggunakan teknologi mutlimedia sebagai media dalam meningkatkan keunggulan bersaing. Menurut Arsyad (2011) multimedia adalah kombinasi atau penggabungan antara teks, grafik, animasi, suara dan gambar sehingga akan menghasilkan suatu informasi, pesan atau isi pelajaran yang bermakna. Sedangkan menurut I. E. Putra (2013) multimedia merupakan sistem yang menggunakan lebih dari satu media presentasi yaitu teks, suara, citra, animasi dan video dimana dibuat secara bersamaan dengan melibatkan pengguna sehingga menghasilkan suatu informasi yang interaktif. Dari berbagai definisi multimedia diatas dapat disimpulkan bahwa mutlimedia lebih banyak menggunakan beberapa perangkat bunyi, gambar, teks, video maupun animasi bergerak sehingga akan menghasilkan suatu perangkat lunak yang menarik, interktif, efektif dan menyenangkan. Penggunaan teknologi multimedia sudah merambah ke semua bidang misalnya dalam penggunaan data profil perusahaan, dibidang pendidikan yaitu pembelajaran yang interaktif, dibidang pemasaran produk, maupun dibidang pemerintahan yaitu penggunaan aplikasi e-goverment. Teknologi multimedia juga sudah mempengaruhi berbagai aspek kehidupan yang ada didunia yaitu dengan adanya penggabungan teknologi ini dengan media komunikasi akan membuat semuanya menjadi lebih bermanfaat. Yuniati (2011) membuat suatu aplikasi pembelajaran bahasa isyarat berbasis multimedia untuk penderita tuna rungu. Menurutnya bahasa isyarat yang disampaikan di aplikasi tersebut adalah pengenalan huruf dan angka sehingga para siswa tuna rungu dapat lebih cepat memahami maksud dari bahasa isyarat tersebut dan selain itu aplikasi ini akan membantu para peserta didik dalam memberikan pembelajaran yang menarik dan interaktif dalam pengenalan huruf dan angka. Sedangkan Novaliendry (2013) membuat sebuah pembelajaran dengan game geografi berbasis multimedia dimana game tersebut akan menampilkan geografi regionalisasi daerah bumi dalam bentuk peta pengetahuan dan negara. Teknologi yang dibuat ini secara otomatis membuat siswa lebih mengenal 
secara mendalam tentang letak geografi dari suatu negara yang ada didunia. Dilihat dari berbagai penelitian yang dibuat dengan menggunakan teknologi multimedia didapat bahwa teknologi ini sangat membantu pengguna dalam memberikan informasi yang bermanfaat dan selain itu para pengguna juga akan menjadi lebih kreatif dalam memahami pengetahuan yang disampaikan melalui teknologi multimedia tersebut.

\section{Teknologi Informasi dalam proses pembelajaran}

Berdasarkan Undang-Undang Nomor 20 Tahun 2003 tentang Sistem Pendidikan Nasional menyebutkan bahwa pendidikan nasional berfungsi mengembangkan kemampuan dan membentuk watak serta peradaban bangsa yang bermartabat dalam rangka mencerdaskan kehidupan bangsa. Al-Tabany (2014) mengatakan pendidikan adalah salah satu bentuk perwujudan kebudayaan manusia yang dinamis dimana akan selalu berkembang. Oleh karena itu perkembangan pendidikan diikuti dengan adanya perubahan kebudayaan hidup masyarakat, artinya perbaikan pendidikan akan selalu ditingkatkan sesuai dengan kepentingan perkembangan jaman. Selain itu pendidikan menjadi hal yang sangat penting dalam mencerdaskan kehidupan bangsa, karena dengan menghasilkan generasi yang kreatif dan cerdas dapat mempengaruhi kemajuan suatu negara. Pondasi pokok dari pendidikan adalah sistem pembelajaran yang inovatif dan kreatif sehingga dapat membuat proses belajar mengajar menjadi lebih menyenangkan dan bermanfaat bagi para generasi muda. Selama ini sistem pembelajaran yang ada bersifat konseptional artinya sistem pembelajaran hanya bersifat tatap muka didepan kelas sehingga para siswa menjadi tidak menikmati proses belajar mengajar. Kesuksesan dalam menghasilkan output yang siap bersaing adalah dilihat dari cara pentransferan ilmu pengetahuan para proses belajar mengajar.

Permasalahan yang sering terjadi di dunia pendidikan adalah pembelajaran pendidikan yang bersifat formal dimana transfer ilmu pengetahuan yang dilakukan pada saat proses pembelajaran belum maksimal sehingga daya serap peserta didik masih rendah. Ini dikarenakan kebanyakan guru atau tenaga pengajar belum mau menggunakan alat atau bahan praktek dalam proses pembelajaran dan kebanyakan hanya menjelaskan teori secara konseptual saja dari buku ajar dan referensi lain sehingga membuat para peserta didik tidak terlalu bersemangat dalam memahami bagaimana belajar. Selain itu Al-Tabany (2014) juga mengatakan bahwa kebanyakan siswa hanya menghafal konsep dan kurang mampu menggunakan konsep tersebut jika menemui suatu masalah di masyarakat sehingga proses belajar mengajar membuat kecewa apalagi jika dikaitkan dengan pemahaman terhadap materi. 
Sapto (2009) mengatakan bahwa efektivitas pembelajaran dapat dilakukan dengan memperhatikan suasana yang berkesan sehingga proses belajar mengajar menjadi lebih menyenangkan, selain itu keberhasilan dari proses pembelajaran dapat dilihat dari suatu tindakan terhadap hasil belajar siswa. Menurut Sahlan \& Prastyo (2012) media pembelajaran dapat memberikan kontribusi dalam pemahaman terhadap materi ajar dan nilai pendidikan yang berkarakter, sehingga media bisa dikatakan dapat mewakili apa yang ingin diucapkan dan disampaikan oleh tenaga pengajar sehingga peserta didik menjadi mudah untuk memahami materi pembelajaran yang diberikan. Penggunaan media juga dapat diperuntukan dalam membantu siswa dalam menangkap pengetahuan yang disampaikan oleh tenaga pendidik. Media pembelajaran yang banyak dipergunakan dan mudah didapat saat ini adalah media dalam penggunaan teknologi informasi .

Dalam penggunaan teknologi informasi banyak sekali hambatan dan tantangan yang dihadapi untuk melakukan perubahan pada proses belajar mengajar dikelas. Menurut Wardani (2015) ada beberapa permasalahan yang dihadapi pada saat menggunakan Teknologi Informasi sebagai media pembelajaran yaitu :

a. Guru belum siap dalam memanfaatkan dan menggunakan kemajuan teknologi tersebut padahal para siswa rata-rata sudah memiliki ketertarikan dalam mengikuti perkembangan teknologi informasi sebagai media pembelajaran yang nantinya dapat meningkatkan motivasi belajar siswa

b. Guru sebagai tenaga pengajar masih belum menguasai penggunaan teknologi informasi metode pembelajarannya karena kebanyakan mereka mengalami kesulitan dalam penguasaan pembuatan media pembelajaran berbasis IT

Untuk menghadapi permasalahan tersebut dalam penggunaan teknologi informasi sebagai media pembelajaran, (Asnawir \& Basyiruddin, 2002) menekankan beberapa prinsip dalam penggunaan media oleh tenaga pendidik antara lain :

1. Penggunaan media pembelajaran hendaknya dipandang sebagai bagian integral dalam proses pembelajaran sehingga akan menjadi keharusan dalam menggunakan media tersebut

2. Media pembelajaran dengan teknologi informasi harus dianggap menjadi sumber belajar dalam memecahkan suatu permasalahan dalam proses pembelajaran

3. Guru hendaknya dapat menguasai teknik penggunaan media pembelajaran berbasis teknologi informasi 
4. Guru harus paham dalam penggunaan multimedia agar proses belajar mengajar dapat merangsang motivasi belajar siswa sehingga siswa semakin memahami materi pendidikan karakter.

Adapun beberapa media pembelajaran yang menggunakan teknologi informasi antara lain sebagai berikut :

1. Presentasi dengan menggunakan aplikasi atau perangkat lunak, sehingga presentasi yang dilakukan oleh tenaga pengajar menjadi lebih menarik. Contohnya adalah penggunaan aplikasi power point (microsoft office), dan rona presentasi

2. Simulasi dengan media teknologi informasi dapat menggunakan teknologi augmanted reality, misalnya untuk proses pengenalan organ tubuh manusia dalam mata pelajaran biologi dimana organ tubuh manusia akan ditampilkan dalam bentuk 3D.

3. Memperkenalkan beberapa mata pelajaran dengan menggunakan film animasi atau multimedia

4. Menggunakan aplikasi interaktif misalnya dalam mata pelajaran bahasa inggris, dimana siswa dapat berinteraktif dengan aplikasi tersebut untuk pengenalan dan pelafalan dalam menggunakan bahasa inggris.

\section{Perkembangan Teknologi Android}

Kemajuan dan perkembangan teknologi sekarang ini mempengaruhi penggunaan alat untuk berkomunikasi dan salah satu teknologi yang terkenal adalah teknologi android. Teknologi android selalu mengalami perkembangan yang pesat setiap saat dengan mengikuti kebutuhan dari penggunanya. Ada beberapa penelitian yang menjelaskan pengertian dari android atau smartphone. Purwanti (2013) mengatakan android merupakan perangkat mobile yang memiliki sistem operasi middleware untuk menjalankan beberapa aplikasi didalamnya. Sedangkan Hernawati (2012) menerangkan bahwa android atau smartphone adalah sebuah device yang memungkinkan untuk melakukan komunikasi yang didalamnya terdapat fungsi Personal Digital Assistant dengan memiliki kemampuan layaknya komputer. Berdasarkan pengertian tersebut bahwa android merupakan perangkat komunikasi mobile yang memiliki kemampuan seperti komputer dimana didalamnya terdapat berbagai macam aplikasi yang mampu menjalankan aplikasi yang ada dikomputer. Perangkat ini juga dapat memberikan informasi yang efektif dan efisien sehingga penggunanya dapat mengakses informasi tersebut 
dimana saja dan kapan saja. Umumnya perangkat android memiliki antarmuka papan ketik virtual dimana pengguna mengaplikasikannya dengan touchscreen atau layar sentuh.

Menurut Purwanti (2013) ada beberapa fitur-fitur yang terdapat dalam android antara lain sebagai berikut :

1. Kerangka aplikasi dimana android memberikan kemudahan kepada penggunanya untuk dapat membangun suatu aplikasi inovatif dimana dapat menyesuaikan terhadap kebutuhan para developer atau pengembang aplikasi.

2. Dalvik Vitual Machine (DVM) adalah suatu mesin vitual yang memiliki memori rendah dan dapat dijalankan pada tenaga listrik yang memiliki daya rendah, selain itu DVM yang menggunakan teknologi kernel Linux juga memiliki kemampuan untuk menjaga dari serangan virus dan hacker (dalam hal keamanan) serta dapat mengatur manajemen memori

3. Browsernya sudah terintegrasi dengan beberapa toolsKit open source.

4. Grafis yang didukung oleh library grafis 2D yang dapat dikustomisasi sesuai dengan keinginan oleh pengguna

5. Sqlite yang merupakan database managemen system berukuran kecil (500KB)

6. Memiliki media pendukung antar lain audio, video, dan gambar dalam beberapa format (MPEG4, MP3, JPG, PNG, GIF, AMR, AAC)

7. GSM Telepon dimana penggunanya dapat melakukan komunikasi baik itu komunikasi telepon maupun komunikasi sms

8. Bluetooth dan Wifi, pengguna dapat menggunakan fasilitas tersebut sehingga dapat melakukan transfer data maupun koneksi internet untuk mendapatkan informasi yang dibutuhkan.

Perkembangan teknologi Android dipengaruhi oleh jenis Sistem Operasi yang berkembang, adapun perkembangannya dari versi sebelumnya adalah sebagai berikut :

a. Android v.1.0 (Apple Pie), android yang dirilis pada tanggal 23 September 2008 memiliki ukuran tampilan layar sebesar 320x480 HVGA dimana android ini pertama kali menggunakan OS android

b. Android v.1.1 (Banana Bread), android yang dirilis pada tanggal 9 Maret 2009 memiliki beberapa pembaruan baik itu dari segi OSnya maupun beberapa fitur aplikasi didalamnya seperti pengiriman dan pemberitauan dengan Gmail, pengiriman pesan 
c. Android v.1.5 (Cupcake) yang dirilis pada tanggal 30 April 2009, yang mana android ini memiliki beberapa kelebihan yaitu dapat mengunggah video keaplikasi youtube atau ke beberapa aplikasi foto lainnya, memiliki virtual keyboard pada layar serta memiliki teknologi bluetooth untuk melakukan transfer data

d. Android v.1.6 (Donut) memiliki kemampuan dalam maintanace galery baik itu foto maupun data serta mampu memodifikasi data dalam bentuk teks yang telah dikirim. Android ini dirilis pada tanggal 15 September 2009

e. Android versi 2.0/2.1 telah dilengkapi dengan beberapa browser dan aplikasi Google Map versi 3.1.2 dan didukung oleh aplikasi flash untuk kamera 3,2 MP dimana android ini dirilis pada tanggal 3 Desember 2009

f. Android v.2.2 (Froyo) yang dirilis pada tanggal 20 Mei 2010, dimana android ini sudah memiliki kemampuan peningkatan kinerja aplikasi dari android-android sebelumnya. Android ini dilengkapi dengan teknologi hotspot wifi

g. Android v.2.3 (Gingerbread) dibuat lebih mengutamakan teknologi terhadap kualitas suara dan tampilan dibandingkan versi sebelumnya, dimana android ini dirilis pada tanggal 6 Desember 2010

h. Android v.3.0 (Honeycom) yang dirilis pada tahun 2011 memiliki kemampuan dalam peningkatan kecepatan grafis dan proses dalam menjalankan aplikasi didalamnya

i. Android v.4.0 (Ice Cream Sandwich) dirilis pada tanggal 19 Oktober 2011 sudah memiliki teknologi face detection untuk membuka kunci layar maupun untuk penghubung aplikasi jarinngan sosial (Komputer, 2012)

Dengan melihat perkembangan android yang ada setiap versi memiliki kemampuan dan selalu berinovasi sesuai dengan kebutuhan penggunanya sehingga penggunanya akan puas dalam menggunakan teknologi tersebut. Ada beberapa penelitian yang menggunakan teknologi android dalam memenuhi kebutuhan penggunanya. Penelitian yang dilakukan oleh (Lubis \& Ikhsan, 2015) membuat suatu aplikasi pembelajaran kimia yang dikembangkan secara ilmiah dengan karakteristik visualisasi yang menarik serta memiliki evaluasi soal yang bervariasi sehingga dapat meningkatkan motivasi belajar siswa. Dan masih banyak penelitian yang dilakukan oleh beberapa penulis dengan memanfaatkan teknologi android dalam pengembangan metode sesuai dengan bidangnya masing-masing. Misalnya (P. K. Putra \& Santoso, 2013) membuat suatu aplikasi toko online berbasis android dimana aplikasi tersebut akan dapat dimanfaatkan oleh para wirausaha sebagai media dalam memperdagangkan barang 
berbasis online sehingga akan memberikan peluang bisnis yang menguntungkan secara finansial. Teknologi android sudah banyak digunakan untuk pengembangan dalam menggunakan kebutuhan sesuai dengan bidangnya masing-masing sehingga dapat membantu pekerjaan menjadi lebih efektif, efisien dan inovatif.

\section{Pembelajaran Ajaran Agama Hindu}

Agama Hindu merupakan agama tertua yang ada di Indonesia yang mengajarkan etika atau susila dalam menjalankan kehidupan yang percaya akan adanya Ida Sang Hyang Widi Wasa/ Tuhan Yang Maha Esa. Dalam menjalankan ajaran agama Hindu perlu adanya pembelajaran pendidikan Agama Hindu baik itu dilaksanakan di sekolah, perguruan tinggi maupun di masyarakat melalui organisasi atau kelembagaan berbasis Hindu. Pembelajaran ajaran agama Hindu merupakan pembelajaran yang berisikan tentang norma dan aturan untuk membimbing manusia dalam menjalankan kehidupannya dimana manusia harus berbuat yang baik demi terwujudnya keadaan yang selaras, damai dan tentram. Selain itu pembelajaran ajaran agama Hindu juga membimbing umatnya untuk selalu memupuk rasa cinta terhadap agamanya dan mau berbuat sesuai dengan ajaranya. Pembelajaran Agama Hindu lebih menekankan pada norma-norma ajaran agama antara lain pembelajaran tentang kepemimpinan hindu, hari suci, tempat suci, kitab suci, susila atau etika yang ada pada ajaran Agama Hindu, upacara serta upakara yang ada didalamnya. Ada beberapa penelitian yang dilakukan dalam meningkatkan pembelajaran ajaran agama Hindu :

1) Menurut (Sudarsana, 2017) bahwa peningkatan mutu pendidikan Agama Hindu dapat dilakukan dengan cara menghargai dan memberdayakan Guru Agama Hindu sesuai dengan prestasi yang dicapai, selain itu peningkatan pendidikan Agama Hindu dapat dilakukan dengan membuat pola interaksi didalamnya yaitu pola interaksi satu arah antara guru dan peserta didik, pola guru anak didik - anak didik guru (feed back) dua arah, pola anak didik - anak didik (anak didik belajar satu sama lain).

2) Penelitian yang dilakukan (RN, 2018) bahwa cara yang digunakan untuk meningkatkan prestasi belajar dalam pembelajaran ajaran Agama Hindu adalah dengan melakukan perubahan model pembelajaran yaitu model pembelajaran inquiri, dimana para siswa disuruh untuk memahami, meneliti, dan mengamati apa yang dialami oleh siswa tersebut dan kemudian di analisa sesuai dengan ajaran agama Hindu.

3) Sedangkan penelitian yang dilakukan oleh (Yosiani, Lasmawan, \& Candiasa, 2014) menggunakan pembelajaran PAIKEM GEMBROT (Pembelajaran Aktif, Kreatif, 
Efektif, Menyenangkan, Gembira dan Berbobot) untuk melakukan pembelajaran Dasa Yama Brata yang merupakan bagian dari Ajaran Agama Hindu, dimana terdapat peningkatan prestasi belajar siswa karena pembelajarannya lebih efektif dan meyenangkan.

Pendekatan dan perubahan metode dalam pembelajaran Ajaran Agama Hindu seperti yang dilakukan pada penelitian-penelitian sebelumnya dapat membantu dalam proses belajar mengajar baik secara formal maupun informal. Pembelajaran Ajaran Agama Hindu menjadi peranan penting dalam mendidikan umat terutama generasi muda, karena generasi muda sebagai penentu dalam memajukan kecerdasan bangsa yang tetap berlandaskan pada Ajaran Agama Hindu. Dalam pembelajaran ajaran Agama Hindu perlu adanya beberapa strategi belajar mengajar agar para peserta didik dapat menerima ajaran tersebut yang dapat disesuaikan dengan karakteristik dalam menjalankan kehidupan sehari-hari. Selain metode pembelajaran yang dirubah sehingga proses belajar mengajar menarik, tenaga pengajar pun harus diperhatikan agar memiliki skill yang dapat melakukan pengembangan perangkat mengajar yang disesuaikan dengan perkembangan teknologi informasi saat ini. Ada beberapa contoh strategi pembelajaran ajaran Agama Hindu yang menggunakan teknologi Informasi antara lain,

1. Teknologi Multimedia, dimana tenaga pengajar dapat menggunakan teknologi tersebut untuk menjelaskan materi yang berkaitan dengan ajaran agama Hindu. Misalnya membuat video singkat pengenalan alam semesta beserta isinya, membuat animasi sederhana dengan memadukan visual gambar dan audio atau suara.

2. Teknologi Internet dapat membantu proses pengembangan pembelajaran ajaran agama Hindu, dimana para peserta didik maupun tenaga pengajar dapat memanfaatkan google dalam mencari bahan ajar yang berhubungan dengan ajaran Agama Hindu yang dapat dilakukan dimana saja dan kapan saja.

3. Tenaga pengajar dapat memanfaatkan aplikasi Microsoft Power Point untuk membantu menjelaskan nilai-nilai atau materi yang ada dalam ajaran Agama Hindu dimana tenaga pengajar dapat mengambil point atau inti materi yang akan disampaikan dan ditayangkan dalam bentuk yang menarik.

Selain menggunakan Teknologi dalam pembelajaran Ajaran Agama Hindu, strategi yang dapat dilakukan adalah dengan melakukan praktek-praktek seperti praktek membuat sarana upacara yajna, praktek yoga, praktek sembahyang dan mempersiapkan sarananya. Sehingga selain mengerti teorinya para peserta didik juga dapat memahami dan dapat mempraktekannya secara 
langsung. Dalam melaksanakan praktek tersebut tenaga pengajar juga mengajak para peserta didik untuk melakukan tirta yatra atau perjalanan spiritual agar para peserta didik lebih mengetahui tempat-tempat suci yang ada di Agama Hindu.

\section{Pemanfaatan teknologi android dalam pembelajaran Hindu}

Pembelajaran Ajaran Agama Hindu saat ini harus memiliki strategi agar para generasi muda pada khususnya dapat menerima ajaran tersebut dan mengimplementasikannya dalam kehidupan sehari-hari. Agar pembelajaran tersebut menarik, maka teknologi memegang peranan penting dalam membuat suatu pembelajaran yang efektif dan efisien. Menurut (Rahma, 2015), anak muda yang menyukai teknologi lebih banyak menggunakan teknologi smartphone atau android untuk mengikuti gaya hidup mereka di era globalisasi dan terbukti dari hasil survei mengatakan bahwa segmen perangkat pintar berbasis android masih menjadi kekuasaan pengguna dikalangan generasi muda. Hasil tersebut menunjukan bahwa salah satu strategi pembelajaran ajaran agama Hindu saat ini adalah dengan menggunakan teknologi pintar berbasis android karena generasi muda Hindu rata-rata menggunakan android untuk memenuhi kebutuhan informasinya.

Ada beberapa contoh aplikasi berbasis android untuk pembelajaran ajaran agama Hindu yang dapat diterapkan antara lain :

1. Aplikasi Playstore yang terdapat pada andorid pada umumnya dapat menyediakan beberapa aplikasi pembelajaran hindu, misalnya aplikasi Bhagavad Gita versi Indonesia yang disediakan playstore berbasis android. Bhagavad Gita yang merupakan Pancama Weda hadir dalam aplikasi Android, memudahkan membawa kitab suci tersebut kemana saja dan dimana saja. Keunggulan dari aplikasi ini adalah tidak membutuhkan koneksi internet dalam arti aplikasi ini bersifat offline. Ada banyak jenis versi aplikasi Bhagavad Gita yang ditawarkan di aplikasi playstore, tergantung para pengguna untuk melihat lengkapnya penyajian dari aplikasi tersebut. Sama seperti kitab suci Bhagavad Gita dalam bentuk buku, aplikasi ini juga menampilkan sloka sesuai dengan babnya. Selain aplikasi Bhagavad Gita, aplikasi playstore juga menyimpan beberapa misalnya buku doa digital. Aplikasi ini memiliki beberapa fitur antara lain doa sehari-hari yang memuat doa bangun tidur, doa makan, doa belajar dan lain-lain, dharma wacana yang dapat memberikan inspirasi bagi pembelajaran ajaran agama Hindu, informasi Pura terdekat dengan pengguna, cek hari 
kelahiran dalam kalender saka, lantunan Gayatri Mantra dan berbagai jenis kidung Panca Yadnya yang dapat memberikan cara melantunkan kidung atau nyanyian suci kepada Tuhan melalui digital.

2. (Indrawan, Bayupati, \& Putri, 2017) membuat suatu aplikasi pembelajaran ajaran agama Hindu tentang Dewata Nawa Sangga berbasis android dengan menggunakan teknologi Augmented Reality. Dewata Nawa Sangga adalah manifestasi Tuhan dalam bentuk perwujudan Dewa yang bertugas menjaga dan menguasai sembilan arah mata angin. Aplikasi ini menampilkan tampilan dalam bentuk scene AR Dewata Nawa Sangga dengan objek 3 dimensi, dimana jika android digerakkan ke suatu arah mata angin maka di android tersebut akan muncul bentuk Dewa penguasa arah mata angin tersebut dengan menampilkan informasi nama, sakti dan senjata yang dimiliki dimana disampaikan dalam bentuk narasi. Tampilan objek dewa tersebut akan bergerak seolah-olah berada didunia nyata. Dalam penelitiannya, aplikasi augmanted reality Dewata Nawa Sangga dapat dijadikan media pembelajaran berbasis android dalam memperkenalkan konsep yang ada pada ajaran Agama Hindu dengan jumlah hasil survei yang didapat adalah melebihi nilai $50 \%$.

3. (Wijaya, Sudana, \& Buana, 2016) membuat suatu aplikasi pembelajaran Hindu dengan memperkenalkan cara membuat ketupat dengan model animasi 3D berbasis android. Ketupat merupakan salah satu bagian dari bebantenan yang digunakan untuk mengadakan upacara dan upakara kegiatan keagamaan umat Hindu. Ada beberapa bentuk ketupat yang digunakan antara lain tipat taluh, tipat gatep, tipat sari, tipat kukur, tipat dampulan, tipat galeng, tipat gangsa, tipat lepet, tipat nasi, tipat sirikan, tipat pusuh dan tipat gong yang memiliki fungsinya masing-masing. Aplikasi ini akan memperkenalkan jenis-jenis tipat yang digunakan dengan menampilkan cara membuatnya dimana ditampilkan dalam video model 3D berbasis android sehingga akan mempermudah dalam proses pembelajaran ajaran agama Hindu khususnya dalam hal pembuatan tipat sebagai sarana upacara dalam agama Hindu.

4. Teknologi Augmanted Reality juga dapat dikembangkan dengan membuat suatu aplikasi pengenalan huruf bahasa sansekerta dimana akan ditampilkan dalam bentuk 3D. Selain huruf yang dibuat dalam bentuk objek tersebut, akan diisi dengan suara sesuai dengan bentuknya, sehingga pengguna akan lebih mudah untuk memahami bentuk dan pelafalan dari huruf sansekerta tersebut. 
Dengan menampilkan berbagai macam inovasi dan teknik pembelajaran berbasis android akan membuat suatu proses belajar mengajar menjadi lebih menyenangkan dan akan memotivasi para generasi muda Hindu untuk tetap melestarikan budaya yang ada. Aplikasi-aplikasi berbasis android dapat diimplementasikan secara langsung kepada para peserta didik untuk dapat membantu para pengajar dalam memperkenalkan berbagai macam materi yang berhubungan dengan pembelajaran ajaran agama Hindu, sehingga proses belajar mengajar akan menjadi efektif dan menyenangkan dimana para siswa dapat mengimplementasikannya di kehidupan sehari-hari.

\section{Kesimpulan}

Ada beberapa hal yang dapat diambil dari penjabaran diatas, bahwa pembelajaran ajaran agama Hindu berbasis android :

1. Mampu memberikan pengaruh terhadap proses belajar mengajar karena tenaga pengajar akan dibantu dalam menyampaikan materi berbentuk simulasi baik itu dalam bentuk video maupun objek 3D sehingga siswa akan merasa lebih menyenangkan dalam belajar

2. Mampu memberikan informasi sesuai dengan materi yang disampaikan dalam ajaran agama Hindu, dan pembelajaran ini juga dapat memberikan kemudahan bagi penggunanya dimana teknologi android merupakan teknologi yang mudah dibawa kemana saja dan dimana saja.

\section{Daftar Pustaka}

Al-Tabany, trianto I. B. (2014). Mendesain Model Pembelajaran Inovati, Progresif, Dan Kontekstual. (T. T. T. Trianto, Ed.) (I). Jakarta.

Amanda, T. (2018). Ada Apa dengan Pendidikan di Indonesia? Jakarta. Retrieved from https://student.cnnindonesia.com/edukasi/20180103112420-445-266335/ada-apadengan-pendidikan-di-indonesia/

Arsyad, A. (2011). Media Pembelajaran. Jakarta.

Asnawir, A., \& Basyiruddin, U. (2002). Media Pembelajaran. Jakarta.

Harun, I. (2015). Efektifitas Penggunaan Teknologi Informasi dan Komunikasi dalam Pembelajaran Pendidikan Agama Islam. Jurnal Kependidikan Islam, 14(2), 175-190. https://doi.org/10.1073/pnas.101304298

Hernawati, K. (2012). Pengenalan Teknologi Sejak Dini Dengan Belajar Sambil Bermain Melalui Smartphone. PROSIDING SEMINAR Nasional Matematika Dan Pendidikan Matematika, (November), 193-204.

Indrawan, I. W. A., Bayupati, I. P. A., \& Putri, D. P. S. (2017). Aplikasi Markerless Augmented Reality Dewata Nawa Sanga Berbasis Android. Merpati, 5(2), 34-41. https://doi.org/http://dx.doi.org/10.1016/S1369-7021(07)70240-7 
Julia Purbasari, R. (1988). Pengembangan Aplikasi ANDROID Sebagai Media Pembelajaran Matematika pada Materi Dimensi Tiga Untuk Siswa SMA Kelas X.

Komputer, W. (2012). Langkah praktis membangun aplikasi sederhana platform android (p. 1). Jakarta. https://doi.org/121121433

Latumakulita, L., \& Montolalu, C. E. J. C. (2011). Sistem Pakar Pendiagnosa Penyakit Ginjal. Jurnal Ilmiah Sains, 11(1), 131-139.

Lubis, I. R., \& Ikhsan, J. (2015). Pengembangan Media Pembelajaran Kimia Berbasis Android Untuk Meningkatkan Motivasi Belajar Dan Prestasi Kognitif Peserta Didik Sma. Jurnal Inovasi Pendidikan IPA, 1(2), 191. https://doi.org/10.21831/jipi.v1i2.7504 Novaliendry, D. (2013). Aplikasi Game Geografi Berbasis Multimedia Interaktif (Studi Kasus Siswa Kelas IX SMPN Rao). Jurnal Teknologi Dan Pendidikan, 6(2), 106-118.

Purwanti, I. (2013). Perancangan Aplikasi Pembelajaran Huruf Hijaiyah Berplatform Android Untuk Madrasah Baca Tulis Al Quran Al-Fattah Desa Widodaren Kabupaten Ngawi. Seminar Riset Unggulan Nasional Informatika dan Komputer FTI UNSA 2013.

Putra, I. E. (2013). Teknologi Media Pembelajaran Sejarah Melalui Pemanfaatan Multimedia Animasi Interaktif. Jurnal TEKNOIF, 1(Oktober), 20-25.

Putra, P. K., \& Santoso, P. (2013). Aplikasi Toko Tas Online Berbasis Android. Dimensi Teknik Elektro, 1(1), 12-17.

Rachman, A., Suhartono, V., \& Purwanto, Y. (2010). Agen Cerdas Animasi Wajah Untuk Game Tebak Kata. Jurnal Teknologi Informasi, 6(April), 1-8.

Rahma, A. (2015). The Influence of Using Smartphone In The Students Activities (The Problems Of MAN 1 Rangat Barat). Jurnal Fisip, 2(2), 1-12.

RN, K. B. (2018). Penerapan Model Pembelajaran Inquiri Sebagai Upaya Untuk Meningkatkan Prestasi Belajar Pendidikan Agama Hindu. Cetta: Jurnal Ilmu Pendidikan, 1(1), 33-40.

Sahlan, A., \& Prastyo, A. T. (2012). Desain Pembelajaran Berbasis Pendidikan Karakter. Yogyakarta.

Sapto, H. (2009). Efektivitas Pemanfaatan Media Audio-Visual Sebagai Alternatif Optimalisasi Model Pembelajaran. Jurnal Edukasi @Elektro, 5(1), 1-10.

Sudarsana, I. K. (2017). Peningkatan Mutu Pendidikan Agama Hindu Melalui Efektivitas Pola Interaksi Dalam Pembelajaran Di Sekolah. Prosiding Semaya 2, (Semaya II), 134142.

Wardani, S. (2015). Pemanfaatan Teknologi Augmented Reality (AR) Untuk Pengenalan Aksara Jawa Pada Anak. Jurnal Dinamika Informatika, 5(November), 1-13. Retrieved from http://ojs.upy.ac.id/ojs/index.php/dinf/article/view/111/80

Wijaya, I. N. A., Sudana, A. A. K. O., \& Buana, P. W. (2016). Membuat Ketupat Dengan Animasi Model 3D Berbasis Android. Merpati, 4(1), 1-9.

Yosiani, P. D., Lasmawan, W., \& Candiasa, I. M. (2014). Pengaruh Model Pembelajaran PAIKEM GEMBROT Berbasis Ajaran Dasa Yama Brata Untuk Meningkatkan Sikap Religius dan Prestasi Belajar PPKn (Studi Eksperimen pada Siswa Kelas VII SMP Negeri 3 Denpasar Tahun Ajaran 2013/2014). Jurnal Program Pascasarjana Universitas Pendidikan Ganesha Program Studi Penelitian Dan Evaluasi Pendidikan, 4, 1-11.

Yuniati, Y. (2011). Pengembangan Perangkat Lunak Pembelajaran Bahasa Isyarat Bagi Penderita Tunarungu Wicara. Jurnal Generik, 6(1), 29-32. 